Leadership: Jurnal mahasiswa manajemen Pendidikan Islam

ISSN (P): 2721-7108, ISSN (E): 2715-0399

DOI : http://dx.doi.org/10.32478/leadership. v3i1.875

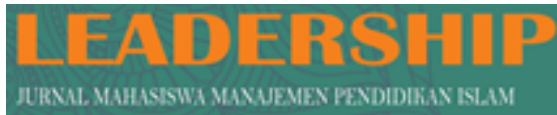

Article Type : Original Research Article

\title{
Manajemen Kesiswaan Di Sekolah Dasar Islam Mohammad Hatta \\ Di Masa Pandemi Covid-19
}

Alfin Nur Zakiyah

STAI Ma'had Aly Al-Hikam Malang, Indonesia

Corresponding author: Email: alvinnurzakiyah9611@gmail.com

Submission Track:

Submisson : :03-01-2022

Accept Submission : 04-01-2022

Avaliable Online : :04-01-2022

Copyright @ 2022 Author

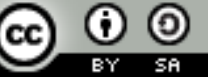

This work is licensed under a Creative Commons Attribution-ShareAlike 4.0

\begin{abstract}
The covid-19 pandemic has had an impact on various aspects of life. With various new policies taken regarding the Covid-19 pandemic, new adaptations are needed for our lives. The existence of the PSBB policy (large-scale social restrictions), social distancing and stay at home forced everyone during this pandemic to carry out all activities from home on an online basis. Likewise in the education sector, which must adapt to new habits related to policies during the Covid-19 pandemic. This research was conducted with the aim of knowing student management at the Mohammad Hatta Islamic Elementary School during the Covid-19 pandemic based on research. This research is a case study research using a descriptive qualitative research approach to describe the findings obtained after the research. The data in this study were collected by means of interviews, observation and documentation study. The research results show that in a managerial system, the activities in this institution have been systematically organized even though they are still adapting to the latest policy updates from the government. This institution strives to continue to optimize student activities amidst the limitations of meeting face to face.
\end{abstract}

\section{Keywords: Student Management, The Covid-19 Pandemic}


Leadership: Jurnal mahasiswa manajemen pendidikan Islam

ISSN (P): 2721-7108, ISSN (E): 2715-0399

Vol. 03 No. 01 bulan Desember 2021

\begin{abstract}
ABSTRAK
Pandemi covid-19 menyebabkan dampak bagi berbagai aspek kehidupan. Dengan berbagai kebijakan baru yang diambil terkait pandemi covid-19 ini maka memerlukan adaptasi baru bagi kehidupan kita. Adanya kebijakan PSBB (Pembatasan Sosial Berskala Besar), social distancing dan stay at home memaksa semua orang pada masa pandemi ini untuk melakukan segala kegiatan dari rumah dengan berbasis online. Begitupula bidang pendidikan, yang harus beradaptasi dengan kebiasaan baru terkait kebijakan pada masa pandemi covid-19. Penelitian ini dilakukan dengan tujuan untuk mengetahui manajemen kesiswaan di Sekolah Dasar Islam Mohammad Hatta di masa pandemi covid-19 dengan berbasis riset. Penelitian ini termasuk dalam jenis penelitian studi kasus dengan menggunkaan pendekatan penelitian kualitatif deskriptif untuk mendeskripsikan hasil temuan yang diperoleh setelah penelitian. Data dalam penelitian ini diambil dengan cara wawancara, observasi dan studi dokumentasi. Hasil penelitian menunjukkan bahwa secara sistem manajerial, kegiatan yang ada di lembaga ini telah tertata secara sistematis meskipun masih beradaptasi dengan update kebijakan terbaru dari pemerintah. Lembaga ini mengusahakan untuk tetap megoptimalkan kegiatan kesiswaan ditengah keterbatasan untuk bertatap muka.
\end{abstract}

Kata kunci : Manajemen Kesiswaan, Masa Pandemi Covid-19

\title{
PENDAHULUAN
}

Pendidikan adalah usaha sadar dan terencana untuk mewujudkan suasana belajar dan proses pembelajaran agar peserta didik secara aktif mengembangkan potensi dirinya untuk memiliki kekuatan spiritual keagamaan, pengendalian diri, kepribadian, kecerdasan, akhlak mulia, serta keterampilan yang diperlukan dirinya, masyarakat, bangsa dan negara. ${ }^{1}$

Peserta didik atau siswa merupakan salah satu sub-sistem yang penting dalam sistem pengelolaan pendidikan di sekolah. Siswa dalam suatu lembaga pendidikan pada dasarnya merupakan masukan yang akan di kelola untuk menjadi output yang di harapkan bagi sekolah. ${ }^{2}$ Siswa adalah mereka yang sedang mengikuti program pendidikan pada suatu sekolah atau pada jenjang tertentu. ${ }^{3}$

Manajemen kesiswaan adalah bagian dari sistem manajemen berbasis sekolah. Manajemen kesiswaan merupakan pengaturan segala aspek aktivitas yang berkaitan dengan peserta didik, yaitu dari mulai masuknya peserta didik (siswa) sampai keluarnya peserta didik (siswa) tersebut dari suatu sekolah atau lembaga pendidikan.

Manajemen kesiswaaan berupaya mengisi kebutuhan layanan yang baik bagi peserta didik, mulai dari siswa tersebut mendaftarkan diri sekolah sampai peserta didik tersebut menyelesaikan studinya. Menurut Depdiknas tujuan pembinaan kesiswaaan antara lain: 1)

1 Pemerintah RI, Undang-Undang RI No. 20 tahun 2003 tentang Sistem Pendidikan Nasional dan Peraturan Pemerintah RI No. 47 Tahun 2008 Tentang Wajib Belajar (Bandung: Citra Umbara, 2012), Hlm 2.

2 Nuzuar, Administrasi dan Supervisi Pendidikan : Teori dan Praktek, (Curup : LP2 STAIN CURUP, 2010), Hlm 29-30

${ }^{3}$ Arsil dan Maria Botifar, Manajemen Pendidikan, ( Curup : LP2 STAIN CURUP, 2013), hlm 64 
mengembangkan potensi peserta didik secara optimal dan terpadu yang meliputi bakat, minat dan kreativitas 2) memantapkan kepribadian peserta didik untuk mewujudkan ketahanan sekolah sebagai lingkungan pendidikan sehingga terhindar dari usaha pengaruh negatif dan bertentangan dengan tujuan pendidikan 3 ) mengaktualisasikan potensi peserta didik dalam pencapaian prestasi unggulan sesuai dengan bakat dan minat 4) menyiapkan peserta didik agar menjadi warga masyarakat yang berakhlak mulia, demokratis, menghormati hak-hak asasi manusia dalam rangka mewujudkan masyarakat madani (civil society). ${ }^{4}$

Peran manajer kesiswaan atau ketika di sekolah biasa disebut waka kesiswaan adalah sangat penting. Keberadaannya sangat penting untuk pengaturan proses pendidikan siswa dari awal hingga akhir sesuai dengan visi dan misi lembaga masing-masing yang tetap berdasarkan tujuan pendidikan nasional.

Sekolah Dasar Islam Mohammad Hatta (SDI Moh Hatta) merupakan sekolah tingkat dasar berbasis Islam yang berada dibawah naungan Yayasan Bina Insan Kamil Indonesia. Belum banyak lembaga pendidikan tingkat dasar yang memiliki struktur manajerial lengkap seperti lembaga pendidikan tingkat menengah/tingkat atas. Kebanyakan di lembaga tingkat dasar yang paling dipentingkan hanyalah bidang kurikulumnya. Namun di lembaga ini mereka sedang mengusahakan adanya keteraturan tidak hanya pada manajemen kurikulumnya saja tapi juga pada manajemen hubungan masyarakat, manajemen saran prasarana dan manajemen kesiswaannya. Bidang humas dan kesiswaan juga tidak kalah penting dengan bidang kurikulum, ke-empat aspek tersebut merupakan penentu keberhasilan suatu pendidikan peserta didik dalam lembaga.

Seperti yang diketahui bahwa Sekolah Dasar Islam Mohammad Hatta memiliki segudang prestasi dalam bidang akademik maupun non akademik. Adanya strategi manajemen kesiswaan yang baik dalam upaya peningkatan kecerdasan, keimanan, ketaqwaan dan prestasi siswa yang sesuai dengan visi dan misi sekolah. Hal ini perlu diketahui oleh lembaga-lembaga pendidikan yang lain untuk diterapkan dalam lembaganya. Sekolah Dasar Islam Mohammad Hatta meskipun merupakan lembaga pendidikan tingkat dasar, mereka sudah melakukan perencanaan matang mulai awal penerimaan siswa kemudian proses pendidikan disekolah, hingga siswa tersebut lulus.

Ditengah hiruk pikuk kesibukan dunia, datanglah sebuah wabah penyakit pada akhir tahun 2019 yaitu virus corona/covid-19 (corona virus disease 2019) yang berasal dari kota Wuhan China. Virus corona merupakan sebuah penyakit menular yang menyerang sistem pernapasan dan parahnya virus ini dapat menyebabkan kematian kepada orang yang terinfeksi. Wortld Health Organization (WHO) menetapkan status pandemi global covid-19 setelah virus berbahaya ini menyebar ke sebagian besar wilayah dunia. Jumlah yang tertular dan korban meninggal terus bertambah sedangkan titik terang pengobatan yang efektif belum ditemukan. Pengumpulan massa dalam jumlah besar telah dihentikan untuk menghindari proses penularan seperti sekolah, kampus, tempat hiburan, konferensi, dan termasuk diantaranya aktivitas ibadah seperti sholat jumat.

Adanya anjuran mengenai social distancing, maka pemerintah membuat sebuah kebijakan untuk stay at home dan PSBB (Pembatasan Sosisal Berskala Besar). Dengan adanya PSBB (Pembatasan Sosial Berskala Besar) ini maka seluruh kegiatan baik perekonomian, pendidikan, pariwisata dan lain sebagainya akan terganggu. Kegiatan belajar mengajar di

\footnotetext{
${ }^{4}$ Depdiknas, Peraturan Menteri Pendidikan Nasional Republik Indonesia Nomor 39 Tahun 2008 Tentang Pembinaan Kesiswaan (Jakarta: Biro Hukum dan Organisasi Departemen Pendidikan Nasional, 2008), Hlm 4.
} 
sekolah pun menjadi tidak dapat dilakukan dengan tatap muka seperti biasanya. Agar roda kehidupan terus berjalan, maka kegiatan daring (via online) pun menjadi pilihan terbaik pada kondisi seperti ini.

Kegiatan di sekolah, baik pembelajaran maupun kegiatan administrasi yang dilakukan secara online tidaklah mudah, sebab memerlukan adaptasi dari yang biasanya berinteraksi secara langsung menjadi secara online. Begitu pula dengan kegiatan manajemen kesiswaan yang akan peneliti bahas kali ini. Seperti yang telah diketahui bahwa kegiatan manajemen kesiswaan merupakan rangkaian kegiatan dari awal siswa masuk hingga siswa telah dinyatakan lulus dari lembaga pendidikan. Runtutan kegaitan tersebut pada masa pandemi ini apabila dilakukan perubahan sistem yang awalnya secara langsung menjadi secara daring (online) maka akan ditemui kendala-kendala di dalamnya. Untuk itu, maka penelitian berbasis riset ini dilakukan dengan tujuan untuk mengetahui secara mendalam problematika yang dialami serta penyelesaian yang dilakukan.

\section{LITERATUR REVIEW}

\section{Manajemen Kesiswaan}

a. Manajemen

Manajemen secara etimologi berasal dari bahasa Inggris yaitu dari kata kerja to manage yang artinya mengurus, mengatur, menggerakkan dan mengelola. Secara terminologi, manajemen berasal dari bahasa Inggris yaitu dari kata kerja to manage yang disinonimkan dengan to hand yang berarti mengurus, to control memeriksa, to guide memimpin. ${ }^{5}$ Apabila dilihat dari asal katanya, manajemen berarti pengurusan, pengendalian atau pembimbing. Dari kata tersebut dapat diambil pengertian manajemen adalah pekerjaan mengatur, mengelola dan juga mengarahkan pada sesuatu yang akan dicapai sesuai dengan urutan fungsifungsinya. Selanjutnya dalam perkembangannya istilah manajemen digunakan untuk mengaendalikan dan mengatur suatu organisasi. George R. Terry mengklarifikasikan bahwa fungsi manajemen terdapat empat bagian yakni perencanaan atau planning, pengorganisasian atau organizing, pelaksaan atau actuating, pengawasan atau controling.

Menurut Parker yang dikutip oleh Husaini Usman, menyatakan bahwa manajemen ialah seni melaksanakan pekerjaan melalui orang-orang (the art of getting things done through people). ${ }^{6}$ Manajemen adalah menjalankan fungsi perencanaan, fungsi pengorganisasian, pengerakan, dan pengendalian menjadi suatu rangkaian kegiatan pengambilan keputusan yang bersifat mendasar dan menyeluruh dalam proses pendayagunaan segala sumberdaya secara efisien disertai penetapan cara pelaksanaannya oleh seluruh jajaran dalam suatu organisasi untuk mencapai tujuan organisasi. ${ }^{7}$

\footnotetext{
${ }_{6}^{5}$ Dita Amanah, Pengantar Manajemen (Medan: UNIMED, 2010), Hlm2.

${ }^{6}$ Husain Usman, Manajemen Teori, Praktik, dan Riset Pendidikan (Jakarta: Bumi Aksara, 2006), Hlm 3.

${ }^{7}$ Syaiful Sagala, Manajemen Strategi dalam Peningkatan Mutu Pendidikan (Bandung: Alfabeta, 2007), Hlm 52.
} 
Leadership: Jurnal mahasiswa manajemen pendidikan Islam

ISSN (P): 2721-7108, ISSN (E): 2715-0399

Vol. 03 No. 01 bulan Desember 2021

Dari beberapa pengertian diatas, maka dapat disimpulkan bahwa Manajemen merupakan proses yang dilakukan agar suatu usaha dapat berjalan dengan baik memerlukan perencanaan, pemikiran, pengarahan, dan pengaturan serta mempergunakan/mengikutsertakan semua potensi yang ada baik personal maupun material secara efektif dan efesien.

b. Kesiswaan

Kesiswaan berasal dari kata dasar siswa dalam kamus Bahasa Indonesia berarti Murid, Pelajar ${ }^{8}$ yang mendapat imbuhan ke-an yang berarti segala sesuatu yang menyangkut dengan peserta didik atau yang lebih populer dengan siswa. Secara etimologi, siswa adalah siapa saja yang terdaftar sebagai objek didik di suatu lembaga pendidikan. ${ }^{9}$

c. Manajemen kesiswaan

Mujamil Qomar memberikan definisi manajemen kesiswaan adalah pengelolaan kegiatan yang berkaitan dengan peserta didik mulai dari awal masuk (bahkan sebelum masuk) hingga akhir (tamat) dari lembaga pendidikan. ${ }^{10}$ Manajemen kesiswaan merupakan salah satu bidang operasional Manajemen berbasis sekolah (MBS). Manajemen kesiswaan adalah seluruh proses kegiatan yang direncanakan dan diusahakan secara sengaja serta pembinaan secara kontinu terhadap seluruh peserta didik (dalam lembaga pendidikan yang bersangkutan) agar bisa mengikuti proses PBM dengan efektif dan efesien. ${ }^{11}$

Manajemen kesiswaan merupakan proses pengurusan segala hal yang berkaitan dengan peserta didik di suatu sekolah mulai dari perencanaan, penerimaan, pembinaan selama peserta didik berada di sekolah, sampai peserta didik menamatkan pendidikan melalui penciptaan suasana yang kondusif terhadap berlangsungnya proses belajar mengajar yang efektif. ${ }^{12}$

Manajemen kesiswaan bertujuan untuk mengatur berbagai kegiatan dalam bidang kesiswaan agar kegiatan pembelajaran di sekolah dapat berjalan dengan lancar, tertib, teratur, serta mencapai tujuan pendidikan sekolah. Untuk mewujudkan tujuan tersebut, bidang manajemen kesiswaan sedikitnya memiliki tiga tugas utama yang harus diperhatikan, yaitu penerimaan siswa baru, kegiatan kemajuan belajar (pengelolaan proses pembelajaran), serta bimbingan dan pembinaan disiplin. ${ }^{13}$

Dengan demikian dapat disimpulkan bahwa manajemen kesiswaan merupakan suatu usaha untuk melakukan pengelolaan peserta didik mulai dari peserta didik tersebut masuk sekolah sampai dengan mereka lulus, layanan yang memusatkan perhatian pengaturan, pengawasan, dan layanan peserta didik di kelas dan diluar kelas demi kelangsungan dan peningkatan mutu sehingga lembaga pendidikan

\footnotetext{
${ }^{8}$ JS. Badudu dan Sutan M. Zain, Kamus Umum Bahasa Indonesia (Jakarta: Pustaka Sinar Harapan, 1994), Hlm 1338.

${ }^{9}$ Suharsimi Arikunto, Pengelolaan Kelas dan Siswa (Jakarta:Rajawali, 1986), Hlm 11.

${ }^{10}$ Mujamil Qomar, Manajemen Pendidikan Islam: Strategi Baru Pengelolaan Lembaga Pendidikan Islam (Jakarta: Erlangga, 2007), Hlm 141

11 Mulyono, Manajemen Administrasi dan Organisasi Pendidikan (Yogyakarta: Ar-Ruzz Media, 2008), HIm 178.

12 Soetjipta dan Raflis Kosasi, Profesi Guru (Jakarta: PT. Rineka Cipta, 2004), Hlm 165.

${ }^{13}$ Sri Minarti, Manajemen Sekolah, (Jogyakarta : Ar-Ruzz, 2012), Hlm 156
} 
Leadership: Jurnal mahasiswa manajemen pendidikan Islam

ISSN (P): 2721-7108, ISSN (E): 2715-0399

Vol. 03 No. 01 bulan Desember 2021

tersebut dapat berjalan dengan teratur, dan terkontrol dengan baik sehingga menjadi sumber daya manusia yang memiliki potensi tinggi dan berdaya guna.

\section{Masa Pandemi Covid-19}

Coronavirus 2019 (covid-19) adalah penyakit menular yang disebabkan oleh sindrom pernapasan akut coronavirus 2 (sars-CoV-2). Penyakit ini pertama kali ditemukan pada desember 2019 di Wuhan, Ibukota Provinsi Hubei China, dan sejak itu menyebar secara global, mengakibatkan pandemi coronavirus 2019-2020. Organisasi kesehatan masyarakat dunia (WHO) mendeklarasikan wabah coronavirus 2019-2020 sebagai Kesehatan Masyarakat Dunia Internasional (PHEIC) pada 30 januari 2020, dan pandemi pada 11 maret 2020. Wabah penyakit ini begitu sangat mengguncang masyarakat dunia, mengingat hampir 200 Negara di Dunia terjangkit oleh virus ini termasuk Indonesia.

Berbagai upaya pencegahan penyebaran virus covid-19 pun dilakukan oleh pemerintah di negara-negara di dunia guna memutus rantai penyebaran virus covid-19 ini, yang disebut dengan istilah lockdown dan social distancing. ${ }^{14}$ Dengan adanya kebijakan lockdown dan PSBB (Pembatasan Sosial Berskala Besar) ini maka seluruh kegiatan baik bidang perekonomian, pendidikan, pariwisata dan lain sebagianya akan terganggu. Upaya pencegahan ini juga diberlakukan dalam dunia pendidikan. Oleh karena itu dunia pendidikan melakukan kegiatan pembelajaran jarak jauh dengan semboyan dirumah saja merupakan pilihan yang terbaik untuk kondisi saat ini sampai diumumkan kembali berlakunya kegiatan belajar mengajar secara tatap muka.

\section{METODE PENELITIAN}

Penelitian ini menggunakan pendekatan penelitian kualitatif deskriptif untuk mendeskripsikan hasil temuan yang diperoleh setelah penelitian. Dan dengan jenis penelitian studi kasus yang mana peneliti melakukan penelitian fenomena kontemporer secara utuh dan menyeluruh pada kondisi yang sebenarnya dengan menggunakan berbagai sumber data.

Menurut Kirk dan Miller dalam Lexy J. Moleong mendefinisikan bahwa penelitian kualitatif adalah tradisi tertentu dalam ilmu pengetahuan sosial yang secara fundamental bergantung pada pengamatan terhadap manusia dalam kawasannya sendiri dan berhubungan dengan orang-orang tersebut dalam bahasanya dan dalam peristilahannya. ${ }^{15}$ Suharsimi Arikunto mengungkapkan bahwa penelitian kualitatif adalah sebagai prosedur penelitian yang menghasilkan data deskriptif berupa kata-kata, tulisan atau lisan dari perilaku orang-orang yang diamati. ${ }^{16}$

Berdasarkan pemaparan diatas, penelitian kualitatif adalah prosedur penelitian yang menghasilkan deskripsi berupa kata-kata dalam bahasa penelitian yang berasal dari pengamatan terhadap manusia dan kondisi yang terjadi pada lingkungan dimana terjadinya penelitian.

Jenis penelitian studi kasus, Merriam dan Tisdell mendefinisikan studi kasus sebagai deskripsi dan analisis mendalam dari bounded system. Yin mendefinisikan studi kasus sebagai

\footnotetext{
${ }^{14} \mathrm{https} / / /$ en.wikipedia.org/wiki/Coronavirus_disease_2019

${ }^{15}$ Lexi J Moloeng, Metodologi Penelitian Kualitatif, (Bandung : Remaja Rosdakarya, 2006), Hlm 6

${ }^{16}$ Suharsimi Arikunto, Prosedur Penelitian; Suatu Pendekatan Praktek, (Yogyakarta : PT. Rineka Cipta, 1998), Hlm 131
} 
Leadership: Jurnal mahasiswa manajemen pendidikan Islam

ISSN (P): 2721-7108, ISSN (E): 2715-0399

Vol. 03 No. 01 bulan Desember 2021

proses penelitian. Studi kasus digunakan untuk memberikan pemahaman akan sesuatu yang menarik perhatian, proses sosial yang terjadi, peristiwa konkret, atau pengalaman orang yang menjadi latar latar dari sebuah kasus. Sebuah studi kasus penelitian bertujuan untuk menguji pertanyaan dan masalah penelitian, yang tidak dapat dipisahkan antara fenomena dan konteks dimana fenomena terjadi. ${ }^{17}$

Penelitian ini dilakukan dengan berbasis riset, yaitu dengan mengkaji seluruh kegiatan manajemen kesiswaan di SD Islam Mohammad Hatta terutama pada saat pandemi covid-19. Pengumpulan data dilakukan dengan cara observasi kegiatan kesiswaan disekolah dan wawancara kepada pihak-pihak yang berkaitan dengan kegiatan kesiswaan.

\section{HASIL}

A. Gambaran Umum SD Islam Mohammad Hatta

\section{Profil}

SD Islam Mohammad Hatta Malang dirintis oleh Prof. H. Masruchin Ruba'i, SH., MS. serta prakarsa para cendekia-cendekia Muslim yang kompeten, professional dan peduli akan tumbuh kembang anak serta perjuangan Islam. Berdasarkan hasil pertimbangan dan kesepakatan, maka pada tahun 2003 para perintis/cendekia Muslim bersatu untuk mendirikan pendidikan dasar yang bernafaskan keislaman dengan nama SD Islam Mohammad Hatta, yang berdomisili di Jl. Kamelia no. 30 / J. Simpang Flamboyan no. 30 Malang, yang bernaung di bawah Yayasan Bina Insan Kamil ( YANAIKA ) Malang.

Pada tanggal 8 Desember 2004, turun surat keputusan (SK) mendirikan/menyelenggarakan SD Islam Mohammad Hatta Malang dengan nomor SK.421.8/5429/420.304/2004 dari Direktorat Pendidikan Dasar dan menengah Kota Malang. Dan Perpanjangan ijin opersional nomor : 421.2/3974/2.3/35/73/307/2016 oleh Dinas Pendidikan Kota Malang

Pada tahun 2009 SD Islam Mohammad Hatta Malang dilaksanakan akreditasi sekolah yang membawa pengaruh terhadap turunnya SK nomor 045/BAP$\mathrm{SM} / \mathrm{TU} / \mathrm{X} / 2009$, dari Badan Akreditasi nasional Sekolah/Madrasah Jawa Timur dengan hasil yang sangat menggembirakan yaitu Terakreditasi "A". Tahun 2016 juga dilaksanakan akreditasi dengan hasil yang masih belum dikeluar.

Jumlah siswa SD Islam Mohammad Hatta Malang semakin lama semakin bertambah diikuti oleh bertambahnya jumlah pengajar, fasilitas sekolah atau kualitas pendidikannya. Kepercayaan masyarakat semakin meningkat dalam rangka membantu terciptanya tujuan Pendidikan Nasional.

Dengan pengelolaan dan kerjasama yang baik dari para perintis sekolah, dewan guru serta karyawan/karyawati SD Islam Mohammad Hatta Malang, akhirnya sekolah ini mengalami perkembangan yang cukup pesat. Perkembangan itu dapat dilihat dari peningkatan kuantitas siswa ataupun kualitas pendidikan siswa.

Berkat management yang baik dan perjuangan yang tidak mengenal henti ini, maka kini SD Islam Mohammad Hatta Malang telah menjelma menjadi Sekolah

${ }^{17}$ Unika Prihatsanti dkk, Jurnal : Menggunakan Studi Kasus Sebagai Metode Ilmiah Dalam Penelitian, Vol 2 No 2, 2018, Hlm 126-128 
Leadership: Jurnal mahasiswa manajemen pendidikan Islam

ISSN (P): 2721-7108, ISSN (E): 2715-0399

Vol. 03 No. 01 bulan Desember 2021

Dasar Islam yang berprospek untuk masa depan. SD Islam Mohammad Hatta Malang mempunyai Visi dan misi yang akan membawa sekolah islam tersebut menjadi lebih baik dan maju.

\section{Visi, Misi dan Tujuan}

\section{VISI}

Meletakkan Dasar - dasar Pengembangan Insani yang Cerdas, Berimtaq, Bersahabat dan Berbudaya Lingkungan

MISI

a. Mengintegrasikan muatan keagamaan dan budi pekerti dalam setiap kegiatan pembelajaran.

b. Mengintegrasikan Pendidikan Lingkungan Hidup dalam proses pembelajaran yang berbasis PAIKEM (Pembelajaran Aktif Inovatif Kreatif Efektif dan Menyenangkan).

c. Mengembangkan sarana dan prasarana penunjang proses pembelajaran yang ramah lingkungan.

d. Mengembangkan pembelajaran keterampilan dan teknologi ramah lingkungan yang sesuai bakat dan minat peserta didik.

e. Membudayakan warga sekolah untuk aktif dalam kegiatan perlindungan dan pelestarian lingkungan serta pencegahan perusakan lingkungan dan sumber daya alam.

f. Membangun kerja sama yang harmonis antara sekolah, orang tua, dan masyarakat.

\section{TUJUAN}

Memberikan kemampuan baca tulis, hitung pengetahuan dan keterampilan dasar berkehidupan, kemampuan dasar tentang agama Islam dan pengalamannya sesuai

3. Stuktur organisasi dengan ajaran Islam.

\section{a. Yayasan Bina Insan Kamil Indonesia}

I. Ketua Pembina : Prof. H. Masruchin Ruba'i, SH, MS

Anggota $\quad$ : Ir. H. Marsul Hidayat

II. Pengawas : Prof. Dr. Ir. H. Mochammad Yunus, MS

Anggota $\quad$ : H. Soecipto Abdul Djali

III. Ketua Umum : Prof. H. Bambang Supriyono, MS

IV. Sekretaris : : Muhammad Farid, S.Pd

V. Bendahara : Mahda Chaira. S.TP

VI.Tim Pengembang : : Dra. Hj. Wajdiyah Abdillah

DR. H. Zulfi Mubarak, MA 
Leadership: Jurnal mahasiswa manajemen pendidikan Islam

ISSN (P): 2721-7108, ISSN (E): 2715-0399

Vol. 03 No. 01 bulan Desember 2021

\section{b. Komite Sekolah}
i. Ketua
: Febriyansyah Saltiar.
ii. Sekretaris
: Niken
iii. Bendahara
: Zulfiska, ST.

\section{c. Pimpinan Sekolah}

1) Kepala Sekolah : Suyanto, S.Pd, M.KPd

2) Waka Kurikulum dan Pengajaran : Tomi Ariyansah, S.Pd

3) Waka Sarpras dan Rumah Tangga : : Riesda Januarty, S.Pd

4) Waka Kesiswaan dan Kehumasan: Muhammad Farid, S.Pd

\section{B. Manajemen Kesiswaan SD Islam Mohammad Hatta}

\section{Program Kesiswaan SD Islam Mohammad Hatta}

Dalam menunjang prestasi akademis maupun non akademis siswa membutuhkan kegiatan yang mendukung terciptanya semua hal itu, maka perlu perencanaan yang matang dan konsisten bagi pelaksanaannya. Oleh sebab itu keterkaitan satu komponen dengan komponen lainnya serta koordinasi yang baik diharapkan bisa mempercepat program-program yang ada. Dengan sistem yang baik diharapkan mampu untuk memudahkan dalam mengendalikan setiap program yang ada. Adapun program kesiswaan dari SD Islam Mohammad Hatta adalah :

1. Unit kegiatan keislaman

2. Penguatan pendidikan karakter (PPK)

3. Unit ekstrakurikuler dan pengembangan prestasi

Kegiatan ekstrakurikuler ini selain merupakan kegiatan rutinitas sekolah diluar jam pelajaran, juga merupakan ajang penggemblengan siswa didik sesuai minat dan bakat siswa masing-masing tanpa tekanan, namun bersifat sukarela. Sekolah memiliki misi yang seimbang antara akademik dan non akademik sekolah mempunyai target berkembangnya bakat pribadi siswa serta mampu bersaing dalam lomba-lomba non akademik antar Sekolah Dasar minimal sampai tingkat kecamatan.

Macam-macam kegiatan ekstrakurikuler yang dilaksanakan adalah sebagai berikut:

a. Pendidikan jasmani, olahraga, dan kesehatan
1) Futsal
2) Renang
3) Panahan
4) Dokter kecil

b. Kesenian

1) Seni musik hadrah

2) Seni rupa mewarnai (kelas rendah)

3) Melukis (kelas tinggi) 

4) Teater
5) Pantomim
6) Olah vokal
7) Pidato
8) Dongeng

c. Keagamaan

1) Tahfidz

2) Seni rebana/hadroh

3) MTQ

4) Pildacil

5) Tahfidz khusus

d. Pramuka

1) Pramuka siaga

2) Pramuka penggalang

3) Peringatan hari jadi

4) Persami

e. Life skill

1) Fotografi

2) Robotik

3) Bahasa Inggris

4) Sains Club

5) Public Speaking

4. Unit kesehatan sekolah

Anak merupakan makhluk sosial, unik, kaya dengan fantasi,

5. Unit keorganisasian siswa

6. Unit literasi

2. Kegiatan Manajemen Kesiswaan Pada Masa Pandemi Covid-19

Adanya kebijakan pemerintah tentang Pembatasan Sosial Berskala Besar (PSBB) dan social distancing, maka kegiatan pembelajaran dan kegiatan kesiswaan seperti ekstrakurikuler tidak dapat dilakukan dengan tatap muka. Pada saat pandemi Covid19, SDI Moh Hatta merancang kebijakan khusus, diantaranya :

1) Menon-aktifkan kegiatan ekstrakurikuler untuk menghindari hal-hal yang tidak memungkinkan.

2) Kegiatan lomba-lomba (puisi, adzan, tartil, hafalan dan sebagainya) tetap dilaksanakan jika dengan online. Pihak sekolah juga mengadakan sesi pelatihan dan pembinaan untuk siswa-siswa yang mengikuti lomba.

3) Pemantauan siswa meliputi kegiataan keseharian siswa, karakter siswa, sikapsikap spiritual maupun sosial siswa melalui buku akhbirna

4) Adaptasi kegiatan motivasi 5 menit serta fiqhur-rijal dan fiqhun-nisa melalui online. Pembuatan grup telegram BUMI "Budaya Islami" yang didalamnya ada semua wali murid SDI Moh Hatta. Adanya grup tersebut bertujuan untuk membina anak-anak agar bisa menyampaikan tausiyah/kultum kepada siswa lainnya melalui video. Motivasi 5 menit yang biasanya sebelum pandemi dilakukan sebelum sholat dhuhur, fiqhur-rijal dan fiqhun-nisa yang sebelum pandemi dilakukan pada hari jum'at sebelum sholat juma'at. 
Leadership: Jurnal mahasiswa manajemen pendidikan Islam

ISSN (P): 2721-7108, ISSN (E): 2715-0399

Vol. 03 No. 01 bulan Desember 2021

\section{Mekanisme Penerimaan Peserta Didik Baru}

Sebelum proses penerimaan peserta didik baru, terlebih dahulu para dewan guru melakukan raker (rapat kerja) untuk memanaj kegiatan yang akan dilakukan selama satu tahun kedepan. Terhitung ada 3 kali rapat dalam kegiatan perencanaan kegiatan penerimaan siswa baru (PSB) diantaranya : 1) rapat pembentukan panitian. 2) rapat teknis pemasaran. 3 ) rapat teknis kegiatan observasi.

Kegiatan penerimaan siswa baru (PSB) di SD Islam Mohammad Hatta sebelum pandemi memang sudah berbasis digital (online). Sehingga ketika pandemi pun tidak terjadi banyak perbedaan. Prosedur penerimaan siswa baru pada saat pandemi Covid19 adalah sebagai berikut :

1) Kegiatan pemasaran dilakukan dengan cara online karena siswa tidak bisa mendapatkan brosur secara langsung. Oleh karena itu kegiatan pemasaran dilakukan secara online dengan menggunakan buzzer dan influenzer serta pemasaran melalui media sosial.

2) Pendaftaran penerimaan peserta didik baru dilakukan via online. Tidak ada siswa atau orang tua siswa yang melakukan pendaftaran di sekolah. Calon peserta didik mendaftarkan diri secara online melalui web SDI Moh Hatta

3) Proses seleksi atau dalam hal ini pihak PSB SDI Moh Hatta menyebutnya sebagai observasi. Observasi disini merupakan penjaringan (seleksi) peserta didik tidak berdasarkan pada kemampuan kognitif saja. Kegiatan observasi ini meliputi tes wawancara, tes psikologi, tes calistung dan tes keagamaan.

Lembaga ini menggandeng tim psikologi umum untuk melakukan tes psikologi kepada siswa dengan menggunakan alat tertentu yang telah teruji ke-validannya. Bahkan disini tes psikologi-lah yang menjadi penentu utama peserta didik diterima atau tidak. Kegiatan observasi di masa pandemi ini dilakukan dengan 5 sesi selama 2 hari. Biasanya sebelum pandemi dilakukan hanya dalam 1 hari saja.

4) Penempatan peserta didik di SDI Moh Hatta dilakukan dengan sistem pemerataan siswa (heterogen) di kelas. Dalam satu kelas tidak boleh hanya ada siswa yang unggul dalam segi visual saja, kinestetik saja, atau auditori saja.

\section{Kendala Yang Dialami Dalam Kegiatan Kesiswaan Pada Masa Pandemi Covid-19}

Kendala-kendala yang dialami selama pandemi Covid-19 ini kebanyakan adalah mengenai teknis kegiatan yang tidak dapat dilakukan secara langsung (tatap muka) sehingga dalam pelaksanaannya secara online masih dalam proses adaptasi dengan kebiasaan baru. Berikut kendala-kendala yang dialami manajemen kesiswaan selama masa pandemi covid-19:

1) Dalam kegiatan penerimaan siswa baru

a. Tidak dapat memberikan brosur secara langsung (kegiatan promosi tidak dapat dilakukan secara langsung) kepada calon siswa. Sehingga kegiatan promosi terkesan kurang efektif.

b. Mengatur waktu yang pas dengan calon murid dan calon wali murid, mengatur protokol kesehatan selama kegiatan observasi, mengatur SDM yang dibutuhkan dari pihak psikologi untuk kegiatan observasi pada saat pandemi.

2) Dalam kegiatan pembentukan karakter siswa

a. Tidak bisa memantau langsung karakter siswa secara maksimal. 
b. Tidak bisa memaksimalkan bakat siswa, sikap-sikap yang harus diperoleh siswa disekolah seperti sikap nasionalis dll, sehingga pembentukan karakter siswa menjadi terhambat dan kurang maksimal.

3) Dalam kegiatan ekstrakurikuler

a. Banyak kegiatan ekstrakurikuler yang tidak dapat berjalan, mengingat ada beberapa kegiatan ekstrakurikuler yang berbayar namun apabila dilakukan via online tidak maksimal.

b. Sumber daya manusia atau pembimbing kegiatan ekstrakurikuler yang kurang memadai

c. Ada beberapa kegiatan ekstrakurikuler secara online namun terkendala dengan waktu pelaksanaanya.

\section{PEMBAHASAN}

\section{A. Program Kesiswaan SD Islam Mohammad Hatta}

Wakil kepala sekolah SDI Moh Hatta menyebutkan bahwa segala bentuk kegiatan dari manajemen kesiswaan telah tersusun dalam program kesiswaan sdi moh hatta yang mana didalamnya telah mencakup segala kegiatan beserta target-targetnya mulai dari siswa masuk hingga siswa lulus. Dalam penyusunan program kesiswaan sdi moh hatta tersebut, telah dilakukan perencanaan secara matang yang disesuaikan dengan visi, misi lembaga serta atsar sahabat nabi yang berbunyi "ajarilah anakmu sesuai dengan kondisi zamannya". Maka program kesiswaan di sdi moh hatta bertujuan untuk melatih siswa menghadapi tuntutan zaman yang ada, sesuai dengan bingkai keislaman. Adapun program kesiswaan SDI Moh Hatta secara garis besar adalah sebagai berikut :

1. Unit Kegiatan Keislaman

2. Penguatan Pendidikan Karakter (PPK)

3. Unit Ekstra Kurikuler dan Pengembangan Prestasi

4. Unit Kesehatan Sekolah

5. Unit Keorganisasian Siswa

6. Unit Literasi

\section{B. Kegiatan Manajemen Kesiswaan Pada Masa Pandemi Covid-19}

Masa pandemi covid-19 ini memaksa agar seluruh kegiatan offline ditiadakan. Banyak sekali program kegiatan kesiswaan yang terpaksa dihentikan karena keterbatasan-keterbatasan yang ada akibat pandemi ini. Beberapa kegiatan mungkin dapat dilakukan dengan cara online, namun banyak juga kegiatan yang tidak dapat efektif apabila dilakukan secara online. Hal ini menuntut pihak sekolah agar membentuk kebijakan baru dalam masa pandemi ini.

Kebijakan-kebijakan yang dibuat telah disesuaikan dengan protokol kesehatan pada masa pandemi covid-19 diantaranya

1. Menon-aktifkan kegiatan ekstrakurikuler untuk menghindari hal-hal yang tidak memungkinkan. Praktis untuk kegiatan ekstrakurikuler ditiadakan sebab adanya protokol kesehatan yang mengharuskan untuk sosial distancing.

2. Kegiatan lomba-lomba (puisi, adzan, tartil, hafalan dan sebagainya) tetap dilaksanakan jika dengan online. Pihak sekolah juga mengadakan sesi pelatihan dan pembinaan untuk siswa-siswa yang mengikuti lomba. Siswa yang mengikuti lomba datang ke sekolah untuk pelatihan. 
3. Pemantauan siswa meliputi kegiataan keseharian siswa, karakter siswa, sikap-sikap spiritual maupun sosial siswa melalui buku akhbirna. Sebelum masa pandemi, program kegiatan dari buku akhbirna ini memang telah ada, bentuknya berupa buku dan dilakukan secraa langsung. Namun pada masa pandemi ini sedikit berbeda karena tidak dapat dilakukan secar alangsung, maka pihak sekolah membuat buku akhbirna dengan versi digital melalui google form. Disini pihak sekolah membutuhkan peran orang tua dalam mensukseskan program ini.

4. Adaptasi kegiatan motivasi 5 menit serta fiqhur-rijal dan fiqhun-nisa melalui online. Pembuatan grup telegram BUMI "Budaya Islami" yang didalamnya ada semua wali murid SDI Moh Hatta. Adanya grup tersebut bertujuan untuk membina anak-anak agar bisa menyampaikan tausiyah/kultum kepada siswa lainnya melalui video. Motivasi 5 menit yang biasanya sebelum pandemi dilakukan sebelum sholat dhuhur, fighur-rijal dan fiqhun-nisa yang sebelum pandemi dilakukan pada hari jum'at sebelum sholat juma'at.

Sebelum diputuskan kebijakan diatas, dalam penyususnannya telah melalui beberapa kali rapat dan koordinasi-koordinasi. Megingat hampir seluruh kegiatan baik intra maupun ekstrakurikuler yang tidak dapat dilakukan seprti biasanya.

\section{Mekanisme Penerimaan Peserta Didik Baru}

Sesuai dengan teori manajemen, mekanisme penerimaan peserta didik baru yang diselenggarakan SDI Moh Hatta telah melalui prosedur yang baku. Dimana sebelum melaksanakan penerimaan siswa baru, pihak sekolah melalui intruksi kepala sekolah melakukan penyusunan perencanaan melalui beberapa kali raker (rapat kerja) diantaranya : 1) rapat pembentukan panitia. 2) rapat teknis pemasaran. 3) rapat teknis kegiatan observasi.

Rapat pembentukan panitia dilakukan dengan tujuan agar kegiatan penerimaan siswa baru ini terorganisir dengan baik dengan diplihnya pihak-pihak yang kompeten dalam hal tersebut. Pembentukan panitia ini juga akan menentukan jalannya kegiatan penerimaan siswa baru yang berikutnya. Pentingnya pembentukan panitia ini dilakukan dengan baik mengingat kondisi pada saat pandemi covid-19 yang berbeda dari sebelumnya. Mengadakan kegiatan ditengah pandemi wabah corona memerlukan penyesuaian dengan protokol kesehatan ketat yang telah ditetapkan oleh pemerintah, demi keamanan bersama ditengah pandemi covid-19 ini.

Proses pemasaran sebelum adanya pandemi covid-19 dilakukan dengan cara online dan offline. Pemasaran secara online adalah dengan membagikan brosur melalui sosial media. Sedangkan pemasaran secara offline dilakukan dengan mengunjungi beberapa TK/RA untuk memberikan brosur dan memasarkan secara langsung. Sedikit berbeda dengan pada saat pandemi covid-19, pihak SDI Moh Hatta tidak dapat melakukan kegiatan pemasaran secara langsung (offline) dikarenakan adanya kebijakan stay at home dan PSBB. Pemasaran pada psb masa pandemi ini diutamakan secara online yaitu dengan menggunakan buzzer dan influenzer serta memanfaatkan media sosial sebanyakbanyaknya.

Kegiatan penerimaan siswa baru di SDI Moh Hatta pada saat pandemi tidaklah jauh berbeda dengan pada saat sebelum terjadi pandemi. Metode pendaftaran berbasis 
online telah diterapkan semenjak sebelum terjadinya pandemi. Tidak ada calon siswa yang pergi ke sekolah untuk mendaftarkan diri secara langsung karena memang semua pendaftaran sudah diatur sedemikian rupa untuk melalui web.

Kegiatan selanjutnya yaitu proses penjaringan (seleksi) atau dalam hal ini pihak PSB SDI Moh Hatta menyebutnya sebagai observasi. Kegiatan observasi ini meliputi tes wawancara, tes psikologi, tes calistung dan tes keagamaan. Pihak kesiswaan SDI mengatakan bahwa kegiatan ini sangat penting karena observasi ini tidak hanya sekedar tes penerimaan biasa. Lembaga ini menggandeng tim psikologi umum dalam pelaksanaannya untuk melakukan tes psikologi kepada siswa dengan menggunakan alat tertentu yang telah teruji ke-validannya. Bahkan disini tes psikologi-lah yang menjadi penentu utama peserta didik diterima atau tidak. Kegiatan observasi yang biasanya dilakukan hanya dalam 1 hari pada masa pandemi covid-19 ini dilakukan selama 2 hari dengan membaginya menjadi 5 sesi. Prosedur protokol kesehatan dilakukan.

Penentuan pembagian kelas dilakukan setelah kegiatan observasi selesai. Pembagian kelas didasarkan pada hasil penilaian siswa pada saat observasi. Di sdi moh hatta pembagian kelas bersifat heterogen, yaitu tidak menyama-ratakan antara siswa yang pandai dalam segi visual saja, kinestetik saja atau auditori saja. Pemerataan siswa di kelas ini juga memudahkan wali kelas dalam mengontrol kelas.

\section{Kendala Yang Dialami Dalam Kegiatan Kesiswaan Pada Masa Pandemi Covid-19}

Sejauh ini mungkin kendala-kendala yang dialami dalam kegiatan kesiswaan pada masa pandemi covid-19 adalah kurang maksimal/efektifnya kegiatan yang dilakukan secara online. Karena kegiatan online sendiri-pun terdapat banyak kendalanya baik terkait jaringan, disiplin siswa yang tidak dapat terjangkau oleh pihak sekolah, kondisi karakter siswa yang tidak dapat terkontrol secara menyeluruh.

Oleh sebab itu kegiatan kesiswaan menjadi kurang maksimal sehingga pihak SDI Moh Hatta mengantisipasinya dengan memperbanyak kegiatan melalui online, budaya Islami, PHBI-PHBN secara online dalam rangka meminimalkan karakter siswa yang kurang. Seperti baru-baru ini memberikan kegiatan pembinaan kesehatan gigi melalui zoom.

\section{PENUTUP}

Manajemen kesiswaan di SDI Moh Hatta pada masa pandemi covid-19 ini mengalami beberapa perubahan. Kegiatan kesiswaan yang tidak dapat dilakukan seperti biasanya akibat pandemi covid-19 yang memaksa agar tidak ada kegiatan secara tatap muka. Adaptasi penyesuaian pada masa pandemi dilakukan pihak SDI Moh Hatta dengan tetap mengikuti prosedur sistem manajerial.

Pembaruan segala teknis kegiatan kesiswaan masa pandemi covid-19 ini membutuhkan perencanaan baru dan pengaturan-pengaturan baru, oleh karena itu contohnya dalam kegiatan penerimaan peserta didik baru dilakukan pembaruan dalam teknis dan prosedurnya. Beberapa kegiatan kesiswaan tidak dapat dilakukan dengan maksimal sebab kegiatan secara online juga membawa berbagai kendala tersendiri dalam pelaksanaannya. Pihak sekolah juga tidak dapat mengawasi secara langsung siswa saat belajar di rumah. Meski begitu, pihak 
Leadership: Jurnal mahasiswa manajemen pendidikan Islam

ISSN (P): 2721-7108, ISSN (E): 2715-0399

Vol. 03 No. 01 bulan Desember 2021

sekolah tetap mengupayakan agar siswa memperoleh semua hak-nya di sekolah dengan cara memperbanyak kegiatan secara online baik kegiatan pembelajaran, penyuluhan-penyuluhan dan kegiatan pembinaan.

\section{DAFTAR PUSTAKA}

Amanah, Dita. 2010. Pengantar Manajemen. (Medan: UNIMED).

Arikunto, Suharsimi. 1986. Pengelolaan Kelas Dan Siswa. (Jakarta : Rajawali).

Arikunto, Suharsimi. 1998. Prosedur Penelitian; Suatu Pendekatan Praktek. (Yogyakarta : PT. Rineka Cipta).

Arsil, Maria Botifar. 2013. Manajemen Pendidikan. (Curup : LP2 STAIN CURUP)

Depdiknas. 2008. Peraturan Menteri Pendidikan Nasional Republik Indonesia Nomor 39 Tahun 2008 Tentang Pembinaan Kesiswaan. (Jakarta : Biro Hukum Dan Organisasi Departemen Pendidikan Nasional)

JS. Badudu, Sutan M. Zain. 1994. Kamus Umum Bahasa Indonesia. (Jakarta : Pustaka Sinar Harapan).

Minarti, Sri. 2012. Manajemen Sekolah. (Jogyakarta : Ar-Ruzz)

Moloeng, Lexi J. 2006. Metodologi Penelitian Kualitatif. (Bandung : Remaja Rosdakarya)

Mulyono. 2008. Manajemen Administrasi Dan Organisasi Pendidikan . (Yogyakarta : Ar-Ruzz Media)

Nuzuar. 2010. Administrasi Dan Supervisi Pendidikan : Teori Dan Praktek, (Curup : LP2 STAIN CURUP)

Pemerintah RI. 2012. Undang-Undang RI No. 20 Tahun 2003 Tentang Sistem Pendidikan Nasional Dan Peraturan Pemerintah RI No. 47 Tahun 2008 Tentang Wajib Belajar. (Bandung : Citra Umbara).

Prihatsanti, Unika. 2018. Jurnal : Menggunakan Studi Kasus Sebagai Metode Ilmiah Dalam Penelitian, Vol 2 No 2, 2018.

Qomar, Mujamil. 2007. Manajemen Pendidikan Islam: Strategi Baru Pengelolaan Lembaga Pendidikan Islam. (Jakarta : Erlangga)

Sagala, Syaiful. 2007. Manajemen Strategi Dalam Peningkatan Mutu Pendidikan . (Bandung : Alfabeta).

Soetjipta, Raflis Kosasi. 2004. Profesi Guru. (Jakarta: PT. Rineka Cipta).

Usman, Husain. 2006. Manajemen Teori, Praktik, Dan Riset Pendidikan. ( Jakarta : Bumi Aksara).

Https://En.Wikipedia.Org/Wiki/Coronavirus Disease 2019 